\title{
A Short Educational Program for The Working Staff of a University Hospital: An Intriguing Implementation Strategy for Palliative Care
}

\section{Bir Üniversite Hastanesinin Personeli İçin “Kısa Eğitim Programı”: Palyatif Bakım Iç̧in İlgi Çekici Bir Uygulama Stratejisi}

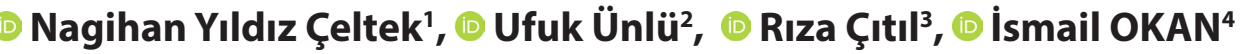 \\ 'Tokat Gaziosmanpasa University School of Medicine Department of Family Medicine, Tokat, Turkey \\ ${ }^{2}$ Tokat Centeral Community Health Center, Tokat, Turkey \\ ${ }^{3}$ Tokat Gaziosmanpasa University School of Medicine Department of Public Health, Tokat, Turkey \\ ${ }^{4}$ Tokat Gaziosmanpasa University School of Medicine Department of General Surgery, Tokat, Turkey
}

\begin{abstract}
Background: Palliative care practice, aimed at improving psychosocial and physical quality of life without the aim of providing medical cure, is under development in our country. We aimed to reveal the implementation strategy and success of a short palliative care education program organized for health workers in our institution.

Method: This descriptive and cross-sectional study was conducted at the Palliative Care Research and Application Centre of Gaziosmanpaşa University in Tokat. As part of implementation strategy, an educational program for all nurses, technicians and other hospital staff (office personnel and etc.) was organised. A test was applied to measure the knowledge levels of the participants in the education program about palliative care before and after the training. The same test was given to hospital personnel who did not participate in the education program after 4 weeks, and pre- and post-test results of attending staff and the test results of non-attending staff were compared and analysed via SPSS Statistic 20 program.

Findings: There were 120 women (63.2\%), 70 men (36.8\%) participants in attending group and 42 women (45.2\%), 51 men (54.8\%) participants in non-attending group. Rate of correct response to 'Which of the following is not suitable for the definition of palliative care?' question, increased $14.7 \%$ and reached $55.8 \%$ in attending group. The non-attending group expressed that they have learned palliative care from attending group with $73.7 \%$.

Conclusions: This study showed that there is a high level of lack of knowledge about palliative care among healthcare workers and that a statistically significant level of awareness can be achieved via a brief education program.
\end{abstract}

Keywords: Palliative Care, awareness, education program, hospital staff
Öz

Giriş: Tıbbi sağaltım amacı olmadan psikososyal ve fiziksel yaşam kalitesini iyileştirmeyi amaçlayan palyatif bakım uygulaması, ülkemizde gelişme aşamasındadır. Çalışmamızda kurumumuzdaki sağlık çalışanları için düzenlenen kısa palyatif bakım eğitim programının uygulama stratejisini ve başarısını ortaya koymayı amaçladık.

Yöntem: Tanımlayıcı ve kesitsel tipteki bu çalışma Tokat Gaziosmanpaşa Üniversitesi Palyatif Bakım Araştırma ve Uygulama Merkezinde gerçekleştirilmiştir. Uygulama stratejisinin bir parçası olarak, tüm hemşireler, teknisyenler ve diğer hastane personeli için bir eğitim programı düzenlenmiştir. Eğitim programına katılanların eğitim öncesi ve sonrası palyatif bakıma dair bilgi düzeylerinin ölçülmesi için bir test uygulanmıştır. Aynı test 4 hafta sonra eğitim programına katılmayan hastane personeline de verilmiş, katılan personelin test öncesi ve sonrası sonuçları ile katılmayan personelin test sonuçları SPSS İstatistik 20 programı ile karşılaştırılmış ve analiz edilmiştir.

Bulgular: Eğitim programına katılan grupta 120 kadın $(\% 63,2)$, 70 erkek $(\% 36,8)$ ve katılmayan grupta 42 kadın (\%45,2), 51 erkek $(\% 54,8)$ bulunmaktaydı. "Aşağıdakilerden hangisi palyatif bakımın tanımı için uygun değildir?" sorusuna doğru yanıt oranı katılan grupta eğitim programı sonrasında \%14,7 artmış, \%55,8'e ulaşmıştır. Eğitim programına katılmayan gruptaki çalışanların \%73,7'si palyatif bakıma dair bilgileri eğitim programına katılan arkadaşlarından öğrendiklerini ifade etmiştir.

Sonuç: Bu çalışma, sağlık çalışanları arasında palyatif bakım konusunda yüksek düzeyde bilgi eksikliğinin olduğunu ve kısa bir eğitim programı ile istatistiksel olarak anlamlı bir farkındalık düzeyine ulaşılabileceğini göstermiştir.

Anahtar Kelimeler: Palyatif bakım, farkındalık, eğitim programı, hastane personeli 


\section{INTRODUCTION}

Palliative care practice, which can be defined as a holistic health service aimed at improving psychosocial and physical quality of life without the aim of providing medical cure, is under development in our country. ${ }^{[1,2]}$ In Turkey, palliative care, which is considered as 'terminal stage patient care', 'supportive care' and 'pain management', has not been fully understood yet. ${ }^{[3]}$ It has been implemented into the healthcare system by the Ministry of health authorities within a framed context and was supported by authorised institutions. In recent years, palliative care units have been opened in many health institutions, especially in tertiary healthcare centres. ${ }^{[4]}$ Palliative care is a holistic, active, and individualised care with family support led by an interdiciplinary team. It is a cloaked form of a form of treatment that has been going on for many years, even though it has come up more frequently in recent years. ${ }^{[5,6]}$ Due to the lack of palliative care competence and curriculum deficiency in traditional education programs, deficiency of health workers about this topic have been emphasied in various studies. ${ }^{[7-9]}$

The palliative care education is not included in the standard medical and nursery curriculum programs. However, palliative care requires knowledge, experience and skills in communication, spirituality, culture and psychosocial issues of patients and their families. Without appropriate information to healthcare personnel, the implementation of palliative care could be quite difficult. Studies have shown that healthcare professionals in palliative care units had problems in communication and decision-making due to lack of knowledge. ${ }^{[10]}$ Palliative care was considered one of the most important topics between 2010-2015 in the agenda of national cancer control program, as PALLIA-TURK project was developed by the Ministry of Health ${ }^{[4]}$ As of 2019, palliative care is provided in 384 centers in 81 provinces. ${ }^{[11,12]}$ However, considering health care workers, patients and their relatives, the level of knowledge and awareness of palliative care is not at the intended point in Turkey. The putative reasons could be the social structure of Turkish society, lack of palliative care in medical curriculum, and lack of awareness in the society and healthcare professionals. ${ }^{[1]}$ As palliative care units open in Turkey, the information requirements of healthcare professional and other staff in hospital increase.

The hospitals are multidiciplinary units functioning as a big and cooperative team. It includes healthcare personal, supporting personal and administrative staff. The harmony among each profession makes the healthcare facility work as a successful and single unit. We decided to inform and train the supporting personal along with healthcare personal about palliative care unit.

Therefore, our study aimed to reveal the results of the palliative care awareness education program organised for hospital staff and healthcare professionals in an university hospital during the implementation of palliative care unit.

\section{MATERIAL AND METHOD}

This descriptive and cross-sectional study was conducted at the Palliative Care Research and Application Centre of Gaziosmanpaşa University in Tokat between 15.10.2015 and 15.02.2016. Our palliative care center started to provide outpatient services as of November 2015 and inpatient services as of November 2017. In order to overcome the lack of information of the both healthcare and hospital staff about palliative care and to introduce our newly opened center, an education program including working principles, target patient groups, multidiciplinary nature of palliative care etc. was organized. The introductory material used for education was prepared by the palliative care working group consisting of surgical oncology, anesthesia, family medicine, emergency medicine, public health, faculty of health sciences academics, volunteer nurse, dietitian, psychologist, social worker and students. Education presentations were made by two responsible physicians. The announcement of the education program was made verbally to the hospital staff through the department supervisors. After the presentation lasting approximately 40 minutes, a discussion of 20 minutes was held. Groups called by partition. A total of 5 education sessions were organized. A test to evaluate the information level of attendants about basic principles of palliative care was prepared by palliative care study group. This test was applied to participants as both pre- (before the presentation) and post- (after the presentation). Four to 6 weeks later from education date, the other personnel who cannot attend education program for different reasons, and working in same departments, were asked to undergo the same test along with a survey which contain 'Do you know palliative care?' and 'Who did you learn palliative care from, how?' questions. Six of these surveys excluded from the study because of missing answers and totally 93 personnel were included in the study as control group.

Acquired data were analyzed via SPSS Statistic 20 program. Descriptive data are indicated by number (n), percentage (\%), Chi-square test was used to test the differences. $p<0.05$ value is accepted statistically meaningful.

\section{RESULTS \\ Demographic Data}

In our study, there were 120 women (63.2\%), 70 men (36.8\%) and mean age of participants was 31.8 in attending group while 42 women (45.2\%), 51 men (54.8\%) and mean age was 34 in non-attending group. Other data are stated on Table 1.

\section{The effect of palliative care education on awareness}

Rate of correct response to 'Which of the following is not suitable for the definition of palliative care?' question, increased $14.7 \%$ and reached $55.8 \%$ in attending group. This ratio is statistically meaningful higher than correct response ratio which is $34.4 \%$ in non-attending group. $(p<0.05)$ About correct response ratio of this question, there was no meaningful difference between control group and pretest of attending group ( $p>0.05)$. 


\begin{tabular}{|lcccc|}
\hline \multicolumn{2}{|c|}{ Table 1. Demographic data about participants } \\
& Attending Group & \multicolumn{2}{c|}{ Control Group } \\
& $\mathbf{n}$ & $\%$ & $\mathbf{n}$ & $\%$ \\
\hline Gender & & & & \\
$\quad$ Male & 70 & 36.8 & 51 & 54.8 \\
Female & 120 & 63.2 & 42 & 45.2 \\
\hline Age & & & & \\
20-29 & 79 & 41.6 & 19 & 21.4 \\
30-39 & 84 & 44.2 & 60 & 64.5 \\
40 and over & 27 & 14.2 & 14 & 15.1 \\
\hline Working years & & & & \\
Less 5 years & 94 & 49.5 & 24 & 25.8 \\
5-9 years & 37 & 19.5 & 33 & 35.5 \\
10 years and more & 59 & 31 & 36 & 38.7 \\
\hline Job & & & & \\
$\quad$ Nurse & 81 & 42.6 & 60 & 64.5 \\
Technician & 85 & 44.7 & 17 & 18.3 \\
Auxiliary hospital staff & 24 & 12.6 & 16 & 17.1 \\
\hline
\end{tabular}

Thinking about 'Palliative care serves to whom' question, ratio of correct response in posttest of attending group is statistically meaningful higher than non-attending group $(p<0.05)$. Similarly about 'definition of ideal palliative care team' question, correct response ratio is statistically meaningful higher in posttest of attending group than non-attending group $(p<0.05)$ (Table 2 ). Similarly in evaluation of these 2 questions there was no meaningful difference between control group and pretest of attending group ( $p>0.05)$.

\begin{tabular}{|c|c|c|c|c|c|c|}
\hline \multirow[b]{2}{*}{ Question } & \multicolumn{2}{|c|}{ Pretest } & \multicolumn{2}{|c|}{ Posttest } & \multicolumn{2}{|c|}{ Control Group } \\
\hline & $\begin{array}{c}\text { Correct } \\
(\%)\end{array}$ & $\begin{array}{c}\text { Wrong } \\
(\%)\end{array}$ & $\begin{array}{c}\text { Correct } \\
(\%)\end{array}$ & $\begin{array}{l}\text { Wrong } \\
(\%)\end{array}$ & $\begin{array}{c}\text { Correct } \\
(\%)\end{array}$ & $\begin{array}{l}\text { Wrong } \\
(\%)\end{array}$ \\
\hline $\begin{array}{l}\text { Which is not suitable } \\
\text { for the definition of } \\
\text { palliative care? }\end{array}$ & 41.1 & 58.9 & 55.8 & 44.2 & 34.4 & 65.6 \\
\hline $\begin{array}{l}\text { Palliative care serves } \\
\text { to whom' }\end{array}$ & 25.8 & 74.2 & 56.3 & 43.7 & 15.1 & 84.9 \\
\hline $\begin{array}{l}\text { Which defines the } \\
\text { ideal palliative team? }\end{array}$ & 63.2 & 36.8 & 88.9 & 11.1 & 47.3 & 52.7 \\
\hline
\end{tabular}

\section{Peer education in palliative care}

Personnel in non-attending group answered "Do you know palliative care?" question as 'yes' 40.9\% and 'no' 51.9\%. About 'Who did you learn palliative care from, how?' questions, it was answered as 'from my friends who participate palliative care education program' $73.7 \%$ and 'other' $26.3 \%$ among participant who express knowing palliative care. 'Do you know palliative care?' question was answered as 'yes' 40.9\% and 'no' $51.9 \%$ by control group. About 'Who did you learn palliative care from, how?' questions, it was answered as 'from my friends who participate palliative care education program' $73.7 \%$ and 'other' $26.3 \%$ among participant who express knowing palliative care.
Thinking of question which valuation of six sentences about palliative care as true or false, five sentences these 1-'Palliative care only deals with the care of terminal stage patients.', 2-'Palliative care is only the duty of physicians interested in this specialty.', 3-'This team should have support after the patient's death.', 4-'Palliative care should be carried out with the concepts of foundation and volunteering.' and 5-'Palliative care aims to evaluate the patient with a holistic approach.' are valuated correctly statistically meaningful higher in posttest of attending group than non-attending group $(p<0.05)$ while there is no statistically meaningful difference in valuation about 'Palliative care should be conducted with a multidiciplinary and interprofessional approach' sentence. ( $p>0.05$ ) About this question when compared of pretest of attending group and control group, it is detected statistically meaningful differences in only 'Palliative care is only the duty of physicians interested in this specialty' and 'Palliative care aims to evaluate the patient with a holistic approach.' sentences. $(p<0.05)$ (Table 3$)$

\begin{tabular}{|c|c|c|c|c|c|c|}
\hline \multirow[b]{2}{*}{ Expressions } & \multicolumn{2}{|c|}{ Pretest } & \multicolumn{2}{|c|}{ Posttest } & \multicolumn{2}{|c|}{ ControlGroup } \\
\hline & $\begin{array}{c}\text { Correct } \\
(\%)\end{array}$ & $\begin{array}{c}\text { Wrong } \\
(\%)\end{array}$ & $\begin{array}{c}\text { Correct } \\
(\%)\end{array}$ & $\begin{array}{c}\text { Wrong } \\
(\%)\end{array}$ & $\begin{array}{l}\text { Correct } \\
(\%)\end{array}$ & $\begin{array}{c}\text { Wrong } \\
(\%)\end{array}$ \\
\hline $\begin{array}{l}\text { Palliative care only } \\
\text { deals with the care } \\
\text { of terminal stage } \\
\text { patients }\end{array}$ & 23.7 & 76.3 & 47.9 & 52.1 & 12.9 & 87.1 \\
\hline $\begin{array}{l}\text { Palliative care is } \\
\text { only the duty of } \\
\text { physicians interested } \\
\text { in this specialty }\end{array}$ & 65.8 & 34.2 & 78.9 & 21.1 & 40.9 & 59.1 \\
\hline $\begin{array}{l}\text { This team should } \\
\text { have support after } \\
\text { the patient's death }\end{array}$ & 93.2 & 6.8 & 95.3 & 4.7 & 86 & 14 \\
\hline $\begin{array}{l}\text { Palliative care should } \\
\text { be conducted with a } \\
\text { multidiciplinary and } \\
\text { interprofessional } \\
\text { approach. }\end{array}$ & 91.6 & 8.4 & 94.2 & 5.8 & 88.2 & 11.8 \\
\hline $\begin{array}{l}\text { Palliative care should } \\
\text { be carried out with } \\
\text { the concepts of } \\
\text { foundation and } \\
\text { volunteering. }\end{array}$ & 81.6 & 18.4 & 97.4 & 2.6 & 86 & 14 \\
\hline $\begin{array}{l}\text { This team should } \\
\text { have support after } \\
\text { the patient's death. }\end{array}$ & 74.2 & 25.8 & 93.7 & 6.3 & 69.9 & 30.1 \\
\hline $\begin{array}{l}\text { Who should give } \\
\text { palliative care first? }\end{array}$ & 41.1 & 58.9 & 55.8 & 44.2 & 34.4 & 65.6 \\
\hline $\begin{array}{l}\text { Where is it better } \\
\text { for palliative care } \\
\text { patients to spend } \\
\text { their final stages? }\end{array}$ & 25.8 & 74.2 & 56.3 & 43.7 & 15.1 & 84.9 \\
\hline
\end{tabular}

There was no significant difference between the attending and control groups in the responses to the questions of support to palliative care due to the philanthropic culture felt in many 
areas in our society. The question 'What is your opinion about supporting palliative care centers?, which was asked to the participants, was highly answered in both groups. (Table 4).

\begin{tabular}{|c|c|c|c|c|c|c|}
\hline \multirow{2}{*}{$\begin{array}{l}\text { What is your } \\
\text { opinion on } \\
\text { supporting } \\
\text { palliative care } \\
\text { centers? }\end{array}$} & \multicolumn{2}{|c|}{ Pretest } & \multicolumn{2}{|c|}{ Posttest } & \multicolumn{2}{|c|}{ Control Group } \\
\hline & number & $\%$ & number & $\%$ & number & $\%$ \\
\hline $\begin{array}{l}\text { I cannot } \\
\text { support }\end{array}$ & 4 & 2.1 & 1 & .5 & 8 & 8.6 \\
\hline $\begin{array}{l}\text { I do not } \\
\text { support }\end{array}$ & 4 & 2.1 & 1 & .5 & 0 & 0 \\
\hline $\begin{array}{l}\text { Economic } \\
\text { support }\end{array}$ & 6 & 3.2 & 7 & 3.7 & 16 & 17.2 \\
\hline $\begin{array}{l}\text { I want to be } \\
\text { a volunteer } \\
\text { support }\end{array}$ & 47 & 24.7 & 51 & 26.8 & 10 & 10.8 \\
\hline $\begin{array}{l}\text { I want to work } \\
\text { part-time }\end{array}$ & 51 & 26.8 & 50 & 26.3 & 23 & 24.7 \\
\hline Social support & 20 & 10.5 & 22 & 11.6 & 36 & 38.7 \\
\hline Total & 190 & 100.0 & 190 & 100.0 & 93 & 100.0 \\
\hline
\end{tabular}

\section{DISCUSSION}

Education program of palliative care was successful in terms of awareness-building for hospital personnel in our institution. Comparing posttest and pretest in education group, recognition of palliative care was higher about questions of target patient population and palliative care team. Similarly comparing posttest education group and control group correct respond rate statistically meaningful higher. Palliative care is defined by World Health Organisation as 'to improve the quality of life of patients and their families through early identification, accurate evaluation and appropriate treatment of pain and many other physical, psychological, social and psychological problems associated with life-threatening diseases..$^{[13]}$ Regarding 'definition of palliative care' question, the fact that rate of correct answer of post-test in attending group is higher and absence of statistically meaningful difference between control group and education group pretest data emphasises importance of education program. In study of Bahçecioğlu et al. with senior students in nursing department, it was seen that participants identified palliative care as 'to improve the quality of life of the individual in the terminal period!. ${ }^{[14]}$ In study of Wechter et al. it was reported that experience in end-of life care in medical education significant contributions for students. ${ }^{[15]}$ In study of Billings et al. in USA it is detected that $35 \%$ of medical students did not encounter any terminal patients. ${ }^{[16]}$

Thinking 'palliative care team' question which examine multi-diciplinary feature, was answered correctly higher in post-test according to non-attending group. In the studies multi-dicipliner feature of palliative care highlighted and emphasied importance of communication and cooperation in coordination for enclosing the patient with a support network. Palliative care team is identified as doctor, nurse, assistant health personnel, volunteers, social worker, religious official and others. ${ }^{[6]}$ Considering cooperation with other related departments and principles of comprehensive and holistic clinic approach, we believe that family physician should be team leader/coordinator of the multidisciplinary palliative team.

Considering the opinions of healthcare workers about expressions with palliative care, rate of correct valuation about sentences which determine palliative care is not only given to end-patients, palliative care is not only the duty of physicians interested in this specialty, palliative care aims to evaluate the patient with a holistic approach, palliative care should be carried out together with the concepts of charity (foundation etc.) and volunteering and this team should have support after the patient's death, is higher in posttest in education group than control group. This result shows that the subjects mentioned in the education are conveyed to the participants.

Similarly considering 'Who should give palliative care first?' question which was prepared for the purpose of to emphasize importance of patient's relatives and 'Where is it best for palliative patients to spend their final stages?' which was prepared for the purpose of to state eligibility to spend the last period at patient's own home, rate of correct answer was statistically meaningful higher in posttest education group than control group. $(p<0.05)$ Literature review show that it is known that many terminal patients, especially cancer patients, want to spend the last stages of their lives at home. Modern medicine approach also suggests that the last period of care at home. In the study of Çıtıl et al. ${ }^{[13]}$ with medical faculty students, it was reported that the majority of the participants expressed their opinion that patients should spend their last period at home. In another study, the coordination of palliative care services and home care units was emphasied in order to achieve this. ${ }^{[17]}$ In the study of Yildizer et al, about 'Where can palliative care be provided?' question $43.7 \%$ of the participants responded as 'in the oncology centers', while only $2.8 \%$ responded as 'at home. ${ }^{\text {[18] }}$ In the study of Gültekin et al with nurse department students it is detected that $42.5 \%$ of the participants think palliative care is appropriate in special palliative care center and $68.3 \%$ of the participants think palliative care which is at home is deficient. ${ }^{[19]}$

Feedbacks about our education program, which was approximately 1 hour, indicated the lack of palliative care education in healthcare workers. In many studies, it was emphasied that one of the problem of the palliative care is the lack of education and training of health workers about symptom management and palliative care skills. ${ }^{[7,8]}$ In the studies, it is detected that when medical students can follow cancer patients or get communication skills education, they are more willingful and well-informed about discussion diffucult topics and helping deciding of patients. However in order to generalize and to be sustainable more education 
programs are needed in longer terms ${ }^{[9,20]}$ In the study of Çıtıl et al. ${ }^{[13]}$ with students of Tokat Gaziosmanpaşa University medical faculty, it is seen that $75.7 \%$ of participants want to get education about palliative care and $44.8 \%$ of want to work in palliative care clinics after graduate. Despite these thoughts of students, awareness of them about palliative care was not at the desired level. In the study of Yıldızer et al. ${ }^{[18]}$ answers of participants against to 'What are the trainings you will need if you have to work in a palliative care center?' are pain management (67\%), pulmoner rehabilitation training (53.4\%), invasive care training $(51.7 \%)$, wound care training $(22.7 \%)$, feeding tube training (20.4\%), mouth care training (11.3\%) and all of these $(5.7 \%)$, respectively.

Palliative care, an area where health workers are often lacking in education and experience, has positive provisions on a voluntary basis in society. In spite of all the problems in the above mentioned about education, the main dynamic of the rapid expansion of palliative care in our country is the high level of volunteering on the subject in society. We have experienced the synergistic effect of our volunteers many times in our own clinic. In our study, in question about supporting the palliative care, the participants stated that they wanted to support the palliative care regardless of the participation in the education program. In the education group, we found that 3 out of 4 people who pointed out that they do not / cannot support choices in the pre-test, changed their answers after education in the direction they wanted to support.

Positive change in the attitudes of the participants about the palliative care practice is more effective than the success of informing for employees in our education program

Limitations: The fact that our study was conducted only in Tokat Gaziosmanpaşa University Health Research and Application Center and inadequate education hours for employees with heavy workloads limited our access to employees.

\section{CONCLUSIONS}

Our study is guiding to show that there is a high level of lack of knowledge about palliative care among healthcare workers (nurses, technicians and auxiliary hospital staff) who provide service to palliative care patients, frequently encountered in a tertiary health care facility, and that a statistically significant level of awareness can be achieved via a brief information education program. We would like to emphasize the importance of supporting healthcare professionals with both licence education and in-service training programs in order to maintain palliative care services that are gaining importance day by day. Many studies have done about palliative care intended for doctors and nurses. High point of our study is targeting to educate not only nurses but also other hospital staff. For effectiveness of these education programs we pay attention to togetherness and work place harmony. Further studies are needed and it should be supplied that palliative care practices can be included in the education curricula of health workers.

\section{ETHICAL DECLARATIONS}

Ethics Comittee Approval: In this research, the data before 2020 was used and the research was concluded before 2020. According to the Regulation on Clinical Researches published in the Official Gazette of the Republic of Turkey with the number 28617 dated 3 November 2015, the ethics committee approval was not obtained in accordance with the article "Retrospective studies are outside the scope of the regulation (article 2- (2))". This study was prepared in accordance with the Law on Protection of Personal Data, by anonymizing patient data and in accordance with the 2013 Brazil revision of the Helsinki Declaration and guidelines for Good Clinical Practice.

Informed Consent: Written informed consent was obtained from all participants who participated in this study.

Status of Peer-review: Externally peer-reviewed.

Conflict of Interest Statement: The authors have no conflicts of interest to declare.

Financial Disclosure: The authors declared that this study has received no financial support.

Author Contributions: All of the authors declare that they have all participated in the design, execution, and analysis of the paper, and that they have approved the final version.

\section{REFERENCES}

1. Kabalak AA, Öztürk H, Çağıl H. Yaşam sonu bakım organizasyonu; palyatif bakım. Yoğun Bakım Derg 2013;11:56-70.

2. Ulusoy SK, Koç ZA, Çayköylü A. Kanser hastalarında palyatif bakım. Turkiye Klinikleri J Psychiatry-Special Topics 2014;7(4):85-8

3. Bingley A, Clark D. A comparative review of palliative care development in six countries represented by the Middle East Cancer Consortium (MECC). J Pain Symptom Manage 2009;37(3):287-96.

4. Uslu FŞ, Terzioğlu F. Dünyada ve Türkiye'de palyatif bakım eğitimi ve örgütlenmesi, Cumhuriyet Hemşirelik Derg 2015;4(2):81-90.

5. Meghani SH. A concept analysis of palliative care in the United States. J Adv Nurs 2004;46(2):152-61.

6. Pastrana T, Jünger S, Ostgathe C, Elsner F, Radbruch L. A matter of definition-key elements identified in a discourse analysis of definitions of palliative care. Palliat Med 2008;22(3):222-32.

7. Paice JA, Ferrell BR, Coyle N, Coyne P, Callaway M. Global efforts to improve palliative care: the international end-of-life nursing education consortium training programme. J Adv Nurs 2008;61(2):173-80.

8. White KR, Coyne PJ, Patel UB. Are nurses adequately prepared for end-oflife care? J Nurs Scholarsh 2001;33(2):147-51.

9. Barclay S, Wyatt P, Shore S, Finlay I, Grande G, Todd C. Caring for the dying: how well prepared are general practitioners? a questionnaire study in wales. Palliat Med 2003;17(1):27-39.

10. Turgay G. Sağlık personelinin palyatif bakıma ilişkin görüşleri, Başkent Üniversitesi Sağlık Bilimleri Enstitüsü hemşirelik anabilim dalı, Yüksek Lisans Tezi, Ankara 2010;31.

11. Kıvanç MM. Türkiye'de palyatif bakım hizmetleri. HSP 2017;4(2):132-5

12. https://khgmozellikli.saglik.gov.tr/svg/palyatif.php Erişim Tarihi: 25.06.2019

13. Çıtıl R, Okan İ, Önder Y, et al. Tıp fakültesi öğrencilerinin palyatif bakım konusundaki farkındalıklarının değerlendirilmesi. Bezmialem Science 2018;6:100-7. 
14. Bahçecioğlu GT, Türben HP, Mankan T. İntörn hemşirelik öğrencilerinin palyatif bakıma ilişkin görüşleri. Cumhuriyet Hemşirelik Dergisi 2017;6(2):54-60.

15. Wechter E, O'Gorman DC, Singh MK, Spanos P, Daly BJ. The effects of an early observational experience on medical students' attitudes toward end-of-life care. Am J Hosp Palliat Care 2015;32:52-60.

16. Billings ME, Engelberg R, Curtis JR, Block S, Sullivan AM. Determinants of medical students' perceived preparation to perform end of-life care, quality of end-of-life care education, and attitudes toward end-of-life care. J Palliat Med 2010;13:319-26.

17. Sullivan AM, Lakoma MD, Block SD. The status of medical education in end-of-life care: a national report. J Gen Intern Med 2003;18:685-95.

18. Yıldızer ÖF, Oğur S. Knowledge and attitudes of health personnel on palliative care: sample of Bitlis province. Journal of Current Researches on Health Sector 2018;8(2):411-38.

19. Gültekin A, Özdemir A, Kavak F. Hemşirelik öğrencilerinin palyatif bakımla ilgili görüşleri. 5. Uluslararsı evde sağlık ve sosyal hizmetler kongresi, 2628 Nisan, Antalya, Bildiri Kitapçığı, 2018;61-5.

20. Gibbins J, Mccoubrie R, Maher J, Wee B, Forbes K. Recognizing that it is part and parcel of what they do: teaching palliative care to medical students in the UK. Palliat Med 2010;24(3):299-305. 